\title{
Choosing a feed evaluation system - NRC vs INRA - to formulate rations for growing goats using minimum cost linear programming
}

\author{
A.L. Martínez Marín ${ }^{1}$, M. Pérez Hernández, L.M. Pérez Alba \\ and A.G. Gómez Castro
}

\author{
University of Cordoba, Department of Animal Production \\ Madrid-Cádiz road, km. 396,14071 Córdoba, Spain
}

(Received 27 August 2009; revised version 31 July 2010; accepted 26 November 2010)

\begin{abstract}
The influence of feed evaluation system and type of forage in the rations for three, eight and twelve months old goats optimized through minimum cost linear programming was studied. The rations included one of three forages (lucerne hay, oat hay or cereal straw). The energy and protein supply and requirements were derived according to NRC (2007) or INRA (2007). The calculated energy intake and the cost of the rations were different between the systems, whereas there were no differences in the calculated intake of protein, forage and concentrate. Cereal straw and oat hay rations were the most cost-effective $(\mathrm{P}<0.05)$ regardless of the age group or the system used. It was concluded that the choice between NRC (2007) and INRA (2007) to formulate rations for young growing dairy goats through minimum cost linear programming is not relevant from both nutritional and economic points of view. Oat hay and cereal straw could be valid substitutes for lucerne hay as roughage source when designing rations for young growing dairy goats.
\end{abstract}

KEY WORDS: goat, feeding, feed formulation, feeding standards, roughages

\section{INTRODUCTION}

Growing replacement goats reared in intensive dairy farms should be fed costeffective rations of easy distribution in the troughs and capable of meeting the

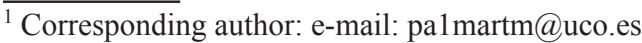


daily nutritional requirements. To formulate such rations through minimum cost linear programming, the nutritionist will need a feed formulation matrix with the price and chemical composition and nutritive value of the available feedstuffs and, on the other hand, the nutritional requirements of the animals. The chemical composition of the feedstuffs can be obtained through chemical or NIR analysis or from published tables of feed composition. The nutritive value of the feedstuffs can be calculated from the chemical composition in accordance with the feed evaluation systems (Institut National de la Recherche Agronomique, INRA; Agricultural and Food Research Council, AFRC; National Research Council, NRC; etc.), from which the nutritional requirements can also be obtained. Each system approaches the evaluation of the nutritive value of the feedstuffs and nutritional requirements of the animals in a different way. So, it can be expected that the cost of the optimized formulas will depend not only on the prices of the feedstuffs included but on the choice of the feed evaluation system too. Studies dealing with the influence of feed evaluation system on the predicted daily requirements of energy, feed intake and feed cost had been conducted in pigs (Schinkel et al., 2008), horses (Martínez Marín, 2009) and dairy cows (Martínez Marín et al., 2010). These studies showed that the differences between the systems compared may be due to the calculated energy requirements, the energy value assigned to the feedstuffs or both.

High production ruminants must be fed rations containing good quality forages. On the other hand, the shortage of forage characteristic of semi-arid zones requires the use of concentrate-rich diets to feed ruminants. Under such conditions, the inclusion of bulky fibrous feeds (low quality hay and crop residues) in diets is an alternative to good quality forages (Susmel et al., 1989). According to Hadjipanayiotou and Morand-Fehr (1991), straw as a roughage source makes an important contribution to the nutrition of goats in many countries with limited supply of good quality forages. The situation may be similar in other low quality forages. Moreover, in areas lacking in good quality forages it could be more economical to feed ruminants concentrate-rich diets rather than high quality forage rations.

The aim of this paper was to ascertain the effect of feed evaluation system (NRC, 2007, and INRA, 2007) and type of forage (lucerne hay, oat hay and cereal straw) on the cost and composition of rations for young growing dairy goats optimized through minimum cost linear programming. 


\section{MATERIAL AND METHODS}

\section{Feed formulation matrix}

Each ration comprised one of three forages - lucerne hay $(\mathrm{LH})$, oat hay $(\mathrm{OH})$ or cereal straw (CS) - and a pelleted concentrate (PC). Nine ingredients were selected to be included in the PC. The chemical composition and calculated nutritive value of the feedstuffs included in the feed formulation matrix are shown in Table 1.

\section{Chemical composition}

The values of chemical composition of the feedstuffs - ash, crude protein (CP), ether extract (EE), crude fibre (CF), neutral detergent fibre (NDF) and acid detergent fibre (ADF) - were taken from the tables NRC (2007).

Energy and protein content of the feedstuffs according to NRC (2007)

NRC (2007) expressed the energy and protein content of the feedstuffs in terms of metabolizable energy (ME) and metabolizable protein (MP). In the present work, the TDN, ME, MP and ruminally undegraded intake protein (UIP) content of the feedstuffs was taken from the tables of NRC (2007). The content of UIP was used to calculate the ruminally degraded intake protein (DIP) content.

Energy and protein content of the feedstuffs according to INRA (2007)

INRA (2007) expressed the energy content of the feedstuffs as milk feeding units (UFL), which is the net energy of lactation (NEL) content of the particular feedstuff relative to that of the French reference barley (1.7 Mcal NEL $/ \mathrm{kg})$. The protein content of the feedstuffs was expressed as protein truly digested in the small intestine (PDI). Two PDI values were calculated, PDIE and PDIN, when rumen available energy or rumen available nitrogen were limiting for microbial growth, respectively. To calculate the NEL, PDIE and PDIN content of the feedstuffs, the set of equations from INRA (2007) was used.

\section{Animals and nutritional requirements}

To calculate the liveweight (LW) and average daily gain (ADG) of the growing goats at three, eight and twelve months old (GG03, GG08 and GG12 group, respectively; Table 2), a growth curve was drawn according to a monomolecular growth model. The parameters set in the model were: $3.2 \mathrm{~kg} \mathrm{LW}$ at birth, $50 \mathrm{~kg}$ LW when adult, approximately 55\% adult LW at first mating at eight months old, and about $75 \%$ adult LW when kidding at thirteen months old. The growth of the conceptus was calculated assuming just a kid per goat. 


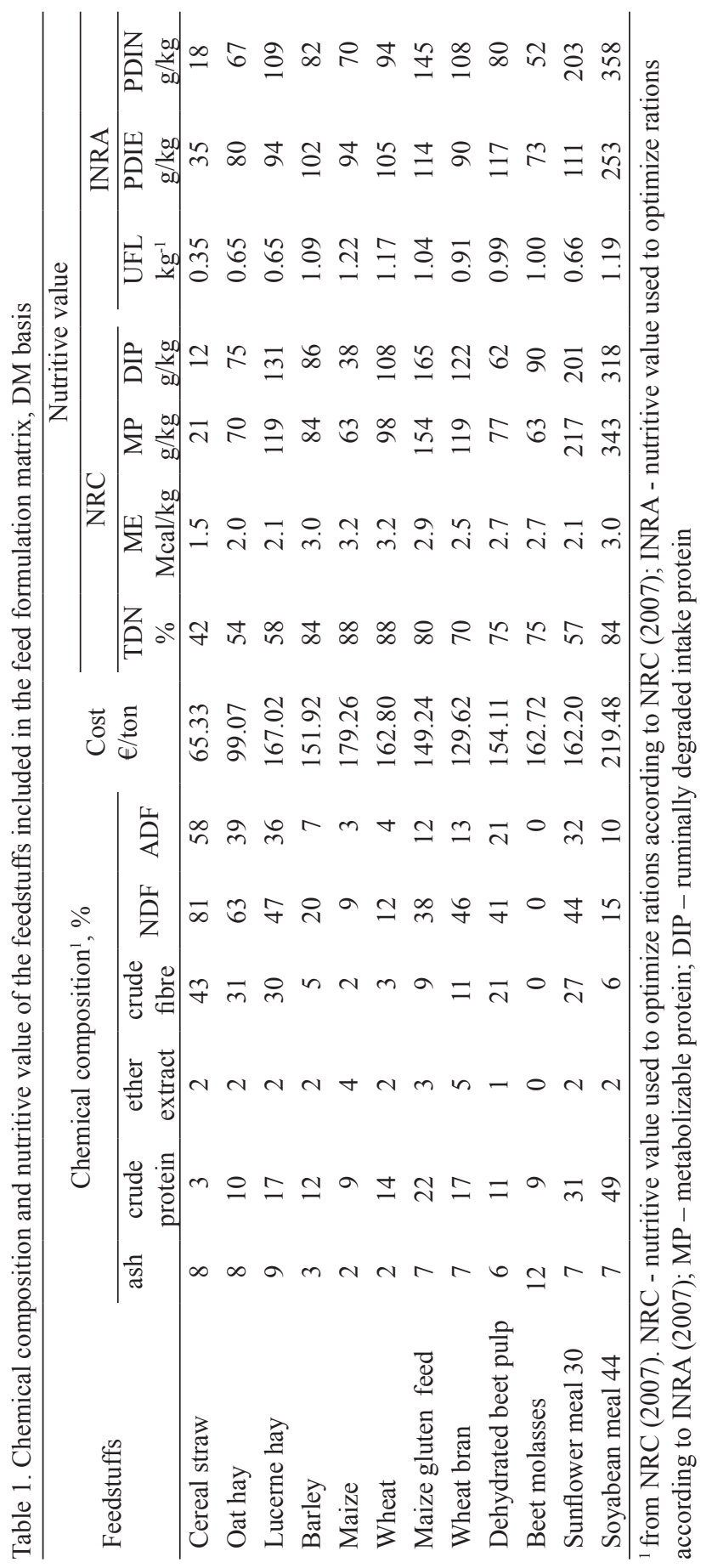


The ME and MP requirements of the goats (Table 2) were calculated using the appropriate NRC equations (NRC, 2007), whereas the UFL and PDI requirements were calculated following the INRA guidelines (INRA, 2007).

To ensure proper rumen function, the minimum amount of long roughage required in all the rations was set at $20 \mathrm{~g}$ per $\mathrm{kg}$ of metabolic $\mathrm{LW}\left(\mathrm{LW}^{0.75}\right)$ according to Bas et al. (1991). No requirements were established for other nutrients. It was assumed that the requirements of minerals, vitamins and trace elements were satisfied with free access to complete lick-blocks.

Table 2. Characteristics and nutritional requirements of the groups of growing goats

\begin{tabular}{lccc}
\hline Item & \multicolumn{3}{c}{ Group } \\
\cline { 2 - 4 } & GG03 & GG08 & GG12 \\
\hline Age, d & 90 & 240 & 350 \\
Liveweight, kg & 16.8 & 31.8 & 38.3 \\
\% adult LW & 34 & 64 & 77 \\
Average daily gain, g & 130 & 70 & 50 \\
Days pregnant & - & - & 110 \\
Requirements & & & \\
ME, Mcal/d & 1.79 & 2.10 & 2.68 \\
MP, g/d & 63 & 61 & 126 \\
UFL, d & 0.54 & 0.72 & 0.90 \\
PDI, g/d & 57 & 51 & 107 \\
\hline
\end{tabular}

GG03 - growing goats, 90 days old; GG08 - growing goats, 240 days old; GG12 - growing goats 350 days old

\section{Limits set in formulation}

The limits set in the formulation are shown in Table 3. The same range of daily DM intake was assumed for each age group in both systems and was calculated as the UFL required per day multiplied by the minimum (1.1) and maximum (1.5) 'volume coefficient' (defined as DM intake:UFL required) recommended by Leroy (1974) for the type of animals studied. The energy limits were expressed as Mcal ME/kg DM in NRC rations or as UFL $/ \mathrm{kg}$ DM in INRA rations; the minimum and maximum values were calculated according to the respective daily energy requirements and the above-mentioned ranges of DM intake.

In INRA rations, the minimum admissible value for the PDIN:PDIE ratio was set at one to avoid a deficit of ruminally available nitrogen relative to energy. The PDI limits were expressed as g PDIE/UFL. In NRC rations, the lower limit for DIP was set at $90 \mathrm{~g} / \mathrm{kg}$ TDN (NRC, 2007). The upper limits for protein supply were set tentatively at $150 \%$ of the minimum calculated requirements in all the rations. 
Table 3. Restrictions applied in the formulation

\begin{tabular}{|c|c|c|c|c|c|c|}
\hline \multirow{2}{*}{ Item } & \multicolumn{2}{|c|}{ GG03 } & \multicolumn{2}{|c|}{ GG08 } & \multicolumn{2}{|c|}{ GG12 } \\
\hline & $\min$ & $\max$ & $\min$ & $\max$ & $\min$ & $\max$ \\
\hline DM intake in both systems, $\mathrm{kg} / \mathrm{d}$ & 0.6 & 0.8 & 0.8 & 1.0 & 0.9 & 1.1 \\
\hline \multicolumn{7}{|l|}{ NRC } \\
\hline energy, Mcal ME/kg DM & 2.24 & 2.99 & 2.10 & 2.63 & 2.43 & 2.97 \\
\hline protein, g MP/Mcal ME & 35 & 53 & 29 & 44 & 47 & 71 \\
\hline roughage, g/Mcal ME & 93 & & 128 & & 115 & \\
\hline $\mathrm{ADF}, \% \mathrm{DM}$ & & 24 & & 24 & & 24 \\
\hline \multicolumn{7}{|l|}{ INRA } \\
\hline energy, UFL/kg DM & 0.68 & 0.90 & 0.72 & 0.90 & 0.82 & 1.00 \\
\hline protein, g PDI/UFL & 105 & 158 & 71 & 107 & 119 & 179 \\
\hline roughage, $\mathrm{g} / \mathrm{UFL}$ & 307 & & 372 & & 342 & \\
\hline $\mathrm{ADF}, \% \mathrm{DM}$ & & 24 & & 24 & & 24 \\
\hline
\end{tabular}

GG03 - growing goats, 90 days old; GG08 - growing goats, 240 days old; GG12 - growing goats 350 days old. Min - minimum inclusion limit, max - maximum inclusion limit. NRC - restrictions applied to the rations optimized according to NRC (2007). INRA - restrictions applied to the rations optimized according to INRA (2007)

The minimum limits for roughage were expressed as $\mathrm{g} / \mathrm{Mcal}$ ME in NRC rations or as g/UFL in INRA rations. The upper limit for ADF was set at $24 \%$ of DM in all the rations according to Lu et al. (2005).

The limits applied to the ingredients to be included in the PC (data not shown) were the same applied in the feed factories where the prices of the feedstuffs were obtained (see below). The limits were set as the upper percentage of each feedstuff that could be included in the concentrate. The price of the feedstuffs (Table 1) was obtained from two feed factories located in Southern Spain and corresponded to the average price from the period of January to December 2006.

The software WinFeed 2.8 (WinFeed, 2006) was used to optimize the eighteen rations at minimum cost.

\section{Statistical analysis}

The statistical software SPSS 15.0 (SPSS, 2006) was used. A three factorial analysis of variance was performed in order to separate clearly the effect of age (growth and growth plus pregnancy), forage quality and feed evaluation system. The model was:

$$
\mathrm{Y}_{\mathrm{ijk}}=\mu+\alpha_{\mathrm{i}}+\beta_{\mathrm{j}}+\gamma_{\mathrm{k}}+\alpha \beta_{\mathrm{ij}}+\alpha \gamma_{\mathrm{ik}}+\beta \gamma_{\mathrm{jk}}+\varepsilon_{\mathrm{ijk}}
$$

where: $Y_{i j k}$ - dependent variable, $\mu$ - general mean, $\alpha_{i}$ - effect of age ( $i=1$ to $3), \beta_{\mathrm{j}}$ - effect of the forage ( $\mathrm{j}=1$ to 3 ), $\gamma_{\mathrm{k}}$ - effect of the system $(\mathrm{k}=1$ to 2$)$, 
$\alpha \beta_{\mathrm{ij}}$ - interaction age $\times$ forage; $\alpha \gamma_{\mathrm{ik}}$ - interaction age $\times$ system, $\beta \gamma_{\mathrm{jk}}$ - interaction forage $\times$ system, $\varepsilon_{\mathrm{ijk}}-$ residual error. Differences among means were determined by Bonferroni test $(\mathrm{P}<0.05)$.

\section{RESULTS AND DISCUSSION}

When optimizing the eighteen intended rations, there were no infeasible solutions. The characteristics of the rations obtained are summarized in Table 4. Nine optimizations satisfied the ME and MP restrictions of NRC (2007), and also calculated the unrestricted UFL and PDI content of the rations. The other nine optimizations satisfied the UFL and PDI restrictions of INRA (2007), and also calculated the unrestricted ME and MP content of the rations. As a result, two energy values (Mcal ME/kg DM and UFL/kg DM) were obtained in every ration. The results of the statistical analysis are shown in Table 5.

Predicted intake of dry matter. The daily DM intake, based on the daily amount needed to meet the calculated energy requirements, differed $(\mathrm{P}<0.05)$ for the type of forage and the system used. The predicted daily DM intake was not different $(\mathrm{P}>0.05)$ for $\mathrm{OH}$ and $\mathrm{CS}$ rations but it was higher $(\mathrm{P}<0.05)$ in comparison with LH rations. The increase in the predicted DM intake with the ageing was due $(\mathrm{P}<0.05)$ to parallel increases in the predicted DM intake of forage and PC; hence, the proportion of forage and concentrate in the rations did not differ significantly $(\mathrm{P}>0.05)$ with age. The significant $(\mathrm{P}<0.05)$ age $\mathrm{x}$ system interaction indicated that the differences in the predicted DM intake between the systems changed with the ageing, i.e. $13.2 \%$ higher in NRC rations for group GG03, but only 1.2 and $2.8 \%$ higher for groups GG08 and GG12.

The predicted total DM intake values obtained for groups GG03, GG08 and GG12 were in agreement with the values derived from mean concentration of ME in the rations according to DLG (2003; $0.68,0.86$ and $0.96 \mathrm{~kg} / \mathrm{d}$, respectively). However, the DM intake predictions estimated in accordance with AFRC (1998) and $\mathrm{Lu}$ and Potchoiba (1990) were slightly higher $(0.82$ and $1.24 \mathrm{~kg} / \mathrm{d}$ and 0.93 and $1.02 \mathrm{~kg} / \mathrm{d}$ for groups GG03 and GG08, respectively). It must be noted that the equations proposed by the systems and authors cited are different, even they use several forms of expressing the energy content of the rations in the calculations, i.e. ME in DLG (2003), metabolizability in AFRC (1998), and digestible energy (DE) in $\mathrm{Lu}$ and Potchoiba (1990). 


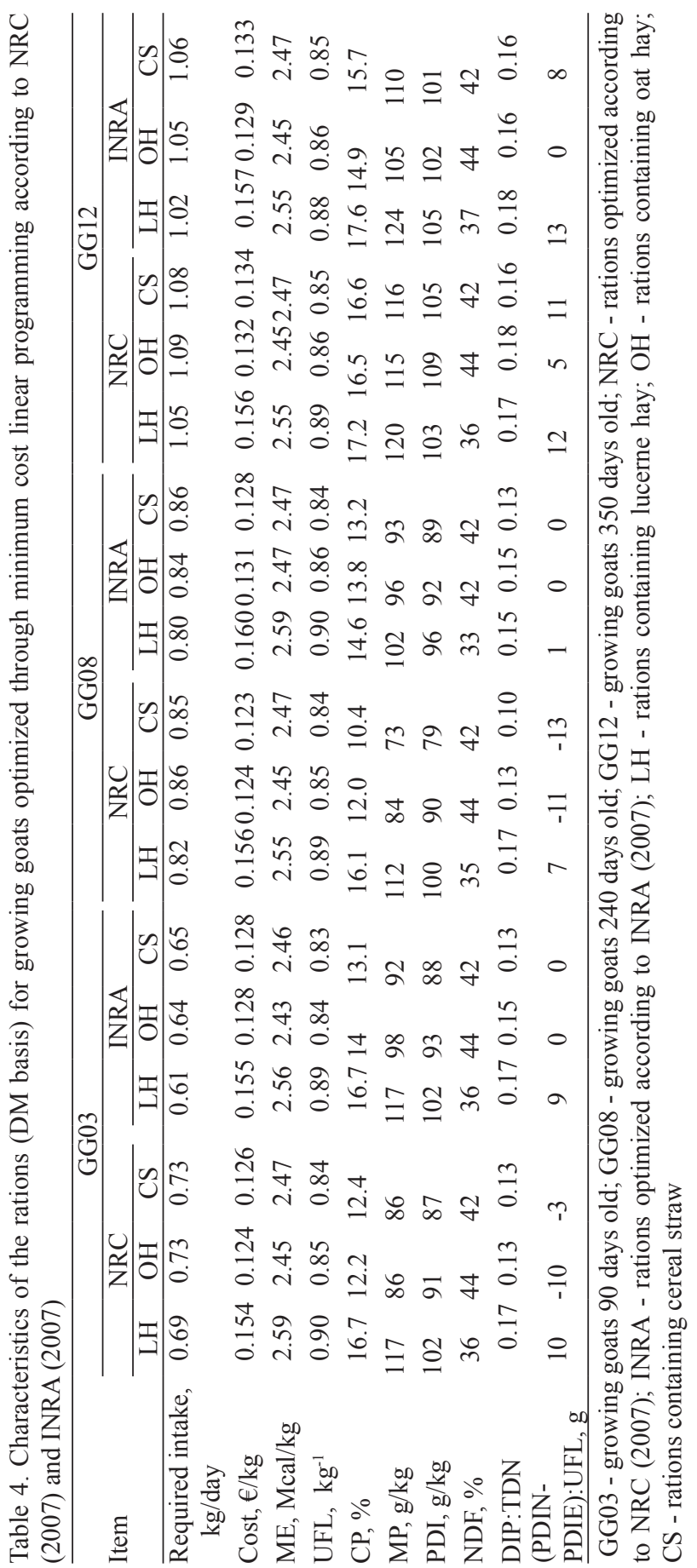




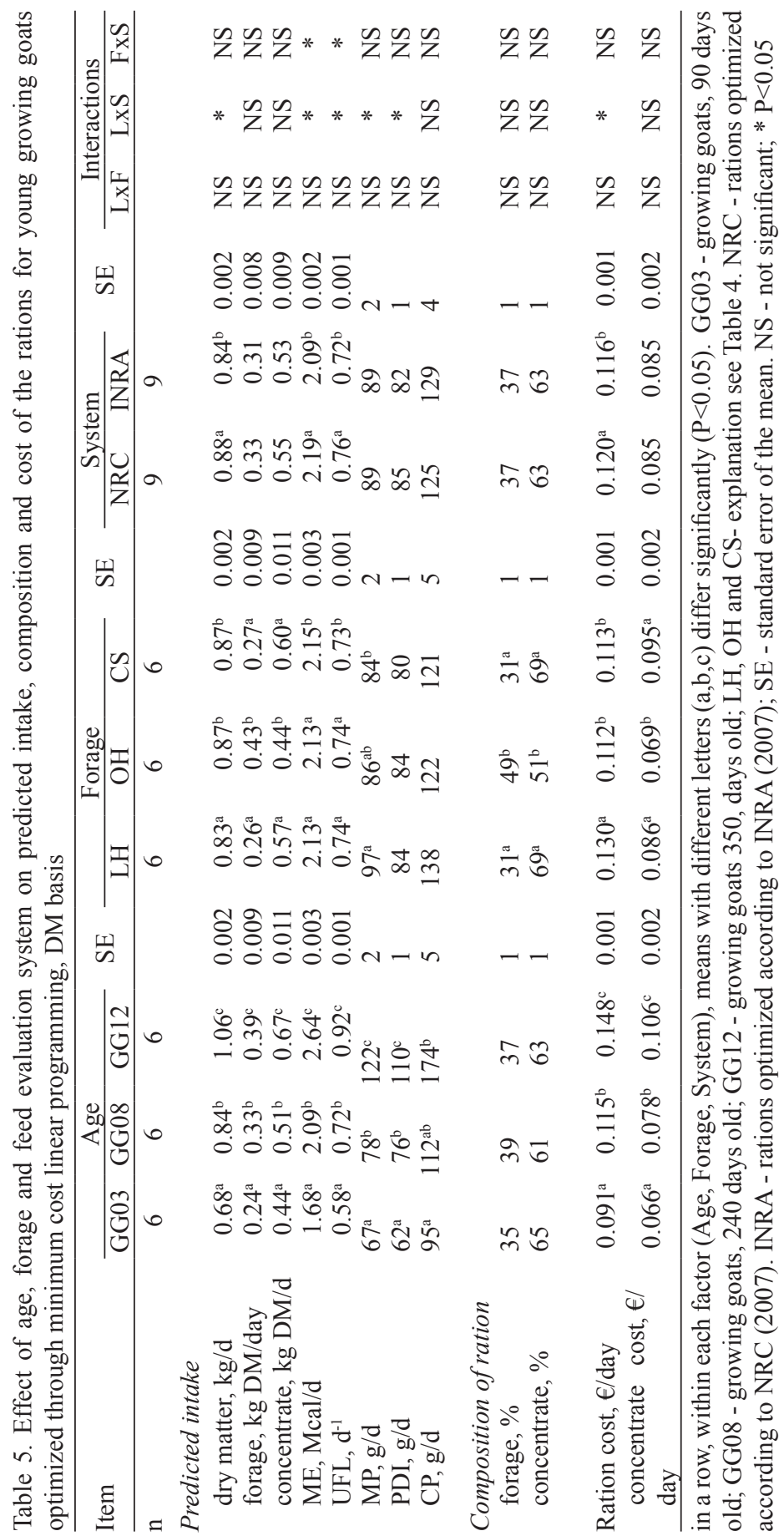


Dry matter intake depends on physical and physiological factors, i.e. gut fill and energy density of the ration. In growing goats aged between three and eight months, Lu and Potchoiba (1990) and Goetsch et al. (2003) suggested a threshold for energy concentration of the ration of about $3.0 \mathrm{Mcal} \mathrm{ME} / \mathrm{kg}$. None of the ration obtained in the present work had more than $2.59 \mathrm{Mcal} \mathrm{ME} / \mathrm{kg}$. On the other hand, Hooper and Welch (1983) found that growing goats with completed development of the rumen had a maximum cell wall intake (including forage and concentrate $\mathrm{NDF}$ ) of about $33 \mathrm{~g} / \mathrm{kg} \mathrm{LW} \mathrm{LW}^{0.75}$. From this value, it can be calculated that the maximum NDF intake would be 274, 442 and $508 \mathrm{~g} / \mathrm{d}$ for groups GG03, GG08 and GG12, respectively. The figure $274 \mathrm{~g} / \mathrm{d}$ is somewhat lower than the predicted intake of NDF in OH and CS ration for group GG03 in NRC (320 and $307 \mathrm{~g} / \mathrm{d}$ ) and suggests that the DM intake could be compromised in such ration. However, one must bear in mind that the maximum ADF content in all the rations was limited to a maximum of $24 \%$ to avoid excessive physical fill as recommended by $\mathrm{Lu}$ et al. (2005) who suggested also that physical fill in growing goats is probably higher than $26 \%$ ADF.

The predicted DM intake of forage and $\mathrm{PC}$ was not different $(\mathrm{P}>0.05)$ for $\mathrm{LH}$ and $\mathrm{CS}$ rations but it was higher $(\mathrm{P}<0.05)$ in comparison with $\mathrm{OH}$ rations. There were no significant differences $(\mathrm{P}>0.05)$ in the predicted DM intake of forage or $\mathrm{PC}$ between the two systems. The predicted DM intake of forage did not reach the maximum levels calculated according to INRA (1978) in any ration: $0.37,0.60$ and $0.70 \mathrm{~kg} / \mathrm{d}$ for CS rations or $0.50,0.80$ and $0.92 \mathrm{~kg} / \mathrm{d}$ for $\mathrm{LH}$ and $\mathrm{OH}$ rations, in groups GG03, GG08 and GG12, respectively. The minimum predicted intake of forage corresponded to LH rations for group GG03 in both systems $(0.17 \mathrm{~kg} / \mathrm{d})$. The maximum predicted intake of forage corresponded to $\mathrm{OH}$ ration for group GG12 in NRC $(0.55 \mathrm{~kg} / \mathrm{d})$. Goetsch et al. (2003) reported similar satisfactory growth rates of Alpine kid goats aged between three and eight months with a DM intake of forage between 0.13 and $0.30 \mathrm{~kg} / \mathrm{d}$, which compares well with the predicted DM intake of forage in the rations for groups GG03 and GG08 (0.17 to $0.34 \mathrm{~kg} / \mathrm{d})$ except for $\mathrm{OH}$ ration for group GG03 in NRC $(0.38 \mathrm{~kg} / \mathrm{d})$ and for group GG08 in both systems $(0.45$ and $0.37 \mathrm{~kg} / \mathrm{d})$.

In their review, Masson et al. (1991) quoted a DM intake of straw by midlactation goats that ranged between 0.30 and $0.80 \mathrm{~kg} / \mathrm{d}$ depending on the quality and accounted at most 20 to $50 \%$ of the energy requirements for maintenance. Across the CS rations, the predicted DM intake of cereal straw would provide between 15 and $20 \%$ of the maintenance energy requirements.

The kind of forage affected $(\mathrm{P}<0.05)$ the proportion of forage and $\mathrm{PC}$ in the rations. $\mathrm{LH}$ and $\mathrm{CS}$ rations had the lowest inclusion percentage of forage and the highest inclusion percentage of $\mathrm{PC}$, whereas the opposite was true in $\mathrm{OH}$ ration resulting in approximate forage:concentrate ratio of 30:70 in LH and CS rations 
and 50:50 in $\mathrm{OH}$ ration. The inclusion percentage of forage and concentrate was not affected $(\mathrm{P}>0.05)$ by the system used. The content of forage oscillated between $24 \%$ (lucerne hay) and 52\% (oat hay) of the predicted total DM intake in every ration obtained in the present work. These values are close to those in the work of Goetsch et al. (2003) that resulted in better growth rates (16 to 46\% DM intake). On the other hand, the average percentage of cereal straw in CS rations for group GG03 was 31\%. Brown and Johnson (1985) observed that the DM digestibility in a ration that contained $35 \%$ wheat straw fed to three months old goats was $71 \%$. It can be calculated that such ration contained $3.16 \mathrm{Mcal} \mathrm{DE} / \mathrm{kg}$. However, the mean calculated DE content in CS ration for group GG03 was $3.04 \mathrm{Mcal} / \mathrm{kg}$. So, it would be expected little, if any, negative effect of cereal straw in our rations.

$\mathrm{Lu}$ and Potchoiba (1990) fed rations based on cottonseed hulls as roughage source to goats aged between four and eight months and did not find differences in ADG when the DE content was 2.76, 3.11 and $3.43 \mathrm{Mcal} / \mathrm{kg}$. In the present work, the DE content of the rations for groups GG03 and GG08 was between 2.95 and $3.17 \mathrm{Mcal} / \mathrm{kg}$.

Energy. There were significant differences $(\mathrm{P}<0.05)$ due to the forage used. LH and $\mathrm{OH}$ rations provided more UFL than $\mathrm{CS}(\mathrm{P}<0.05)$ whereas the opposite was true for $\mathrm{ME}(\mathrm{P}<0.05)$. The significant $(\mathrm{P}<0.05)$ forage $\mathrm{x}$ system interaction indicated differences between INRA (2007) and NRC (2007) in the evaluation of the energy supply depending on the composition of the ration.

A close approach to the relationship between the NEL (expressed as Mcal instead of UFL) and ME content of the ingredients included in the PC revealed that the mean ratio was $0.62(\mathrm{SE}=0.04)$. This figure is equal to the mean efficiency of use of ME for milk production ( $\mathrm{kl})$ value $(0.62 ; \mathrm{SE}=0.02)$ calculated for those ingredients according to INRA (2007). However, the same calculations applied to the forages showed that the NEL/ME ratio and $\mathrm{kl}$ value of lucerne hay and oat hay were similar ( 0.52 and $0.57,0.55$ and 0.57 , respectively) but they were quite different for cereal straw $(0.40$ and 0.53$)$. This difference could be attributable to a low estimation of the NEL content of cereal straw in INRA (2007) or, inversely, to a high estimation of ME content in NRC (2007).

Also, there were significant differences $(\mathrm{P}<0.05)$ due to the system used. NRC rations provided more energy (ME and UFL) than INRA rations. The age $\mathrm{x}$ system interaction pointed to significant differences $(\mathrm{P}<0.05)$ between INRA $(2007)$ and NRC (2007) in the evaluation of the energy requirements for the age groups. The difference in the predicted intake of energy (ME and UFL) was approximately 14, 0.5 and $3 \%$ for groups GG03, GG08 and GG12, respectively.

Although significant, the lack of great differences owing to the system used indicates that they provide a similar evaluation of energy supply of the whole ration and requirements. In fact, the mean value of the NEL/ME ratio in the 
eighteen rations of this work was $0.59(\mathrm{SE}=0.007)$, what compares well with 0.60 $(\mathrm{SE}=0.003)$, the mean $\mathrm{kl}$ value calculated for those rations according to INRA (2007). On the other hand, the ratio between the requirements of NEL and ME according respectively to INRA (2007) and NRC (2007) was $0.51,0.58$ and 0.57 for groups GG03, GG08 and GG12. Except for group GG03, these values are close to 0.59 , the mean $\mathrm{kl}$ value of the rations of Sahlu et al. (2004) which were used to obtain the ME requirements adopted by NRC (2007).

Protein. The predicted intake of MP and PDI was significantly higher $(\mathrm{P}<0.05)$ in $\mathrm{LH}$ rations than in $\mathrm{OH}$ or $\mathrm{CS}$ rations. There were no significant differences $(\mathrm{P}>0.05)$ in the predicted intake of MP and PDI owing to the system used. This could be expected because MP and PDI are the same concept in practice: The amount of protein from rumen microbes plus ruminally undegraded dietary protein digested in the small intestine. However, it is important to note that NRC (2007) calculated the MP of feedstuffs, as a constant proportion of the CP content, based on the indications of NRC (2000) that MP accounts for 64 to $80 \%$ of the CP of the ration for UIP contents between 0 and 100\%. However, INRA (2007) took into account ruminal interrelations between energy and nitrogen as well as the UIP digestibility of the feedstuffs in the small intestine like other feed evaluation systems (AFRC, 1998). Despite the NRC (2007) simplification, the predicted intake of $\mathrm{CP}$ was not different $(\mathrm{P}>0.05)$ between both systems.

INRA (2007) recommended that the PDIN - PDIE difference should not be less than $-14 \mathrm{~g} / \mathrm{UFL}$ in animals fed up to 1.5 times the maintenance energy needs to keep the efficiency of ruminal digestion. INRA (2007) assumed that the shortage of ruminally available nitrogen is covered by the recycling of endogenous urea. $\mathrm{OH}$ and CS rations for groups GG03 and GG08 in NRC were deficient in PDIN. CS ration for group GG08 had the lowest value: $-13 \mathrm{~g} / \mathrm{UFL}$, just in the INRA's limit to be covered by endogenously recycled urea. These results suggest that the estimation of rumen available nitrogen is different between both systems. Moreover, owing to the restrictions imposed on the formulation, the DIP:TDN ratio of all the rations considered in this paper was above the 0.09 value recommended by NRC (2007) with a mean value of $0.15(\mathrm{SE}=0.02)$.

Daily ration cost. The cost differed $(\mathrm{P}<0.05)$ with the kind of forage used. $\mathrm{LH}$ ration were $18 \%$ more expensive than $\mathrm{OH}$ or $\mathrm{CS}$ ration, which had the same cost. In the case of LH ration, the effect of the type of forage on the cost was attributable to the high price, so the lower intake of lucerne hay could not compensate for it. Moreover, the daily cost of the $\mathrm{PC}$ in $\mathrm{LH}$ and CS ration was not significantly different $(\mathrm{P}<0.05)$. However, the daily cost of $\mathrm{OH}$ and $\mathrm{CS}$ ration was similar although the price of oat hay was $52 \%$ higher than that of cereal straw. This was due to a lower daily cost of the $\mathrm{PC}$ in $\mathrm{OH}$ ration compared with the daily cost of the $\mathrm{PC}$ in $\mathrm{CS}$ rations $(\mathrm{P}<0.05)$. There was a significant difference $(\mathrm{P}<0.05)$ owing 
to the system used although it was less than $3.5 \%(0.116$ and $0.120 € / \mathrm{d}$ in INRA and NRC rations). The significant $(\mathrm{P}<0.05)$ age $\mathrm{x}$ system interaction resulted in higher differences between both systems in groups GG03 (12\%) and GG12 (4\%) with no difference in group GG08.

In the present work, the cost per $\mathrm{kg}$ of ration was not relevant. The minimum and maximum energy limits imposed in the formulation corresponded to the energy concentration required to meet the daily requirements when the DM intake was at the maximum and minimum levels, respectively. In this manner, it was possible to optimize through minimum cost linear programming rations that were the most cost-effective on a daily basis regardless of the price in a per $\mathrm{kg}$ basis.

\section{CONCLUSIONS}

The use of NRC (2007) or INRA (2007) to formulate rations for young growing dairy goats through minimum cost linear programming was found to be not relevant from both nutritional and economic points of view. The cost and composition of the rations optimized showed only small differences; this was related to the fact that both systems provided a similar evaluation of energy and protein supply and requirements.

In a context of shortage and/or high price of good quality forages, oat hay and cereal straw could be valid substitutes for lucerne hay as roughage source when designing rations for young growing dairy goats. Moreover, the rations based on oat hay or cereal straw met the restrictions imposed in the formulation as well as those with lucerne hay regardless of age and the system used.

\section{REFERENCES}

AFRC, 1998. The Nutrition of Goats. CAB International, Wallingford (UK)

Bas P., Morand-Fehr P., Schmidely P., 1991. Weaning: a critical period for young kids. In: P. MorandFehr (Editor). Goat Nutrition. European Association for Animal Production. Wageningen, pp. 271-283

Brown L.E., Johnson W.L., 1985. Intake and digestibility of wheat straw diets by goats and sheep. J. Anim. Sci. 60, 1318-1323

DLG, 2003. Recommendations for the Supply of Energy and Nutrients to Goats. DLG-Verlags$\mathrm{GmbH}$, Frankfurt am Main

Goetsch A.L., Detweiler G., Sahlu T., Hayes J., Puchala R., 2003. Effects of separate offering of forage and concentrate on feed intake and growth of Alpine doelings. Small Ruminant Res. 48, 209-216

Hadjipanayiotou M., Morand-Fehr P., 1991. Intensive feeding of dairy goats. In: P. MorandFehr (Editor). Goat Nutrition. European Association for Animal Production. Wageningen, pp. $197-208$ 
Hooper A.P., Welch J.G., 1983. Chewing efficiency and body size of kid goats. J. Dairy Sci. 66, 2551-2556

INRA, 1978. Alimentation des Ruminants. INRA, Paris

INRA, 2007. Alimentation des Bovins, Ovins et Caprins. Editions Quae. Paris

Leroy A.M., 1974. Rational Animal Production (in Spanish). $3^{\text {rd }}$ Edition. Ediciones Gea. Barcelona

Lu C.D., Kawas J.R., Mahgoub O.G., 2005. Fibre digestion and utilization in goats. Small Ruminant Res. 60, 45-52

Lu C.D., Potchoiba M.J., 1990. Feed intake and weight gain of growing goats fed diets of various energy and protein levels. J. Anim. Sci. 68, 1751-1759

Martínez Marín A.L., 2009. NRC vs. INRA to formulate rations based on dry roughages and pelleted concentrates for leisure horses (in Spanish). Arch. Zootec. 58, 333-344

Martínez Marín A.L., Pérez Hernández M., Pérez Alba L., Gómez Castro G., 2010. Effect of feed evaluation system on the cost of rations for dairy cows (in Spanish). REDVET Rev. Electrónica Vet. 11(4), 1-10

Masson C., Rubino R., Fedele V., 1991. Forage utilization in goats. In: P. Morand-Fehr (Editor). Goat Nutrition. European Association for Animal Production. Wageningen

NRC, 2000. Nutrient Requirements of Beef Cattle. National Academy Press. Washington, DC

NRC, 2007. Nutrient Requirements of Small Ruminants. National Academy Press. Washington, DC

Sahlu T., Goetsch A.L., Luo J., Nsahlai I.V., Moore J.E., Galyean M.L., Owens F.N., Ferrell C.L., Johnson Z.B., 2004. Nutrient requirements of goats: developed equations, other considerations and future research to improve them. Small Ruminant Res. 53, 191-219

Schinckel A.P., Mahan D.C., Wiseman T.G., Einstein M.E., 2008. Impact of alternative energy systems on the estimated feed requirements of pigs with varying lean and fat tissue growth rates when fed corn and soybean meal-based diets. Prof. Anim. Sci. 24, 198-207

SPSS, 2006. SPSS Base 15.0 User's Guide, SPSS Inc. Chicago

Susmel P., Spanghero M., Mills C.R., 1989. Intensification of cattle milk production in mediterranean countries: low forage systems. Options Méditerranéennes 6, 79-90

WinFeed, 2006. WinFeed 2.8 Help Documentation, WinFeed (UK) Ltd. Cambridge (UK) 